\title{
Fibrous Carbohydrate Fractions and in Vitro True and Apparent Digestibility of 10 Tropical Forage Grasses ${ }^{1}$
}

\author{
J. Coward-Lord, J. A. Arroyo-Aguili, and O. Garcia-Molinari ${ }^{2,3}$ \\ INTRODUCTION
}

Forage grasses constitute the most economical form of cattle feeding. This is especially so in the Humid Tropic where potential exists for forage production throughout the year. The utilization of forages depends principally upon changes that occur in chemical composition and digestibility during the vegetative cycle.

The Weende scheme of feed analyses (19) has been widely utilized as a means to determine the chemical composition of forage grasses. Recently, Van Soest (30) proposed new methods of analyses based on the use of detergents which render more exact and precise results. Furthermore, in vitro techniques $(6,7,27,34)$, have been developed to estimate digestibility which are simpler, cheaper and considered to be as accurate as in vivo techniques.

The nutritive evaluation of forage grasses utilizing the techniques of Goering and Van Soest (16) is rather limited, especially in the Tropics. For this reason, this methodology was employed in this study to determine chemical composition and in vitro digestibility. The wide margin from 30 to 180 days of plant age, covering 30 -day cutting intervals, offers a better appreciation of the variations in nutritive value at different growth stages of forage grasses.

\section{PROCEDURE}

Ten tropical forage grasses were utilized, of which six are widely known: Pangola (Digitaria decumbens), Congo (Brachiaria ruziziensis), Signal (Brachiaria brizantha), Buffel (Cenchrus ciliaris), Guinea (Panicum maximum) and Jaragua (Hyparrhenia rufa), and four are of potential value: Giant Pangola (Digitaria valida), African Crab (Digitaria swazilandensis),

1 Manuscript submitted to Editorial Board February 28, 1973.

2 Data are taken in part from a thesis submitted by the senior author to the Graduate Faculty, College of Agricultural Sciences, University of Puerto Rico, Mayagüez, P. R., in partial fulfillment of the requirements for the degree of Master of Science.

Assistant Professor of Pastures, Animal Husbandry Department, Faculty of Agronomy, University of Costa Rica, San José, Costa Rica; Associate Nutritionist, Agricultural Experiment Station, University of Puerto Rico, Río Piedras, P. R.; and Professor of Agronomy, Faculty of Agriculture, University of Puerto Rico, Mayagüez, P. R., respectively. 
Venezuelan Elephant (Pennisetum setosum) and Limpo (Hemarthria altissima): The grasses were harvested from established $10 \mathrm{~m}^{2}$ plots at the grass collection of the College of Agricultural Sciences, University of Puerto Rico at Mayagüez.

The plots were lightly fertilized with $\mathrm{NH}_{4} \mathrm{NO}_{8}$ at the rate of $350 \mathrm{~kg} / \mathrm{ha}$. The forages were harvested by hand (machete) every 30 days up to 180 days of age, beginning August 20, 1970, at an approximate height of $10 \mathrm{~cm}$ above soil level. They were weighed at the field, oven-dried at $60^{\circ} \mathrm{C}$ and ground in a Wiley mill to pass through a 1-mm screen.

The techniques of Goering and Van Soest (16) were employed for cell-wall constituents or neutral-detergent fiber (NDF), acid-detergent fiber (ADF), permanganate lignin $(\mathrm{L})$, cellulose $(\mathrm{C})$ and silica (Si). Hemicellulose $(\mathrm{H})$ was determined as the difference between NDF and ADF.

In vitro true dry matter digestibility (IVTD) was determined, utilizing the Tilley and Terry procedure (27) as modified by Van Soest et al. (34) and Goering and Van Soest (16). This technique was again modified in the sense that the artificial rumen system employed was a closed one. In vitro apparent dry matter digestibility (IVAD) was calculated as the difference between IVTD and 12.9 (16), an estimate of endogenous and bacterial excretion. Each grass sample was fermented in quadruplicate, including in each run three forage samples of known in vivo digestibility.

The results obtained were subjected to variance analyses (24).

\section{RESULTS AND DISCUSSION}

Data are presented on dry matter fractionation of the 10 forage grasses at the 6 cutting intervals evaluated. IVTD measurements are also discussed.

\section{NEUTRAL-DETERGENT FIBER}

The NDF content (table 1) is a measure of the total fiber fraction, its difference from 100 being the neutral detergent solubles (NDS) fraction which consist of the soluble nutrients (proteins, lipids, soluble carbohydrates and ash). It includes all organic matter bound into the cell wall, being primarily fibrous carbohydrate (holocellulose) and $\mathbf{L}$, but some of the total forage nitrogen and mineral matter is bound into the fiber (9).

Highly significant ${ }^{4}$ differences in NDF content were obtained between species. The highest mean values were obtained in Guinea, Buffel, and Limpo grasses and differed significantly ${ }^{5}$ from the remaining seven species, where mean values were not significantly different among themselves.

As the grasses matured from 30 to 180 days, highly significant differences in NDF content were obtained, the highest increases being between the 30 -

${ }^{4}$,Significant at the 1-percent level.

6 Significant at the 5-percent level. 
and the 60-day cutting intervals. Similar results were obtained by Tessema (26), confirming that the greatest change in nutrient composition occurred between the 30- and 60-day stages. At 30 days of age, Guinea, Buffel and Pangola grasses were the highest in NDF content. However, Pangola grass increased only by 0.7 percentage units in NDF content between 30 and 60 days, as compared to the sharp increase in other grasses varying from 3.2 to 14.4 percentage units.

\section{ACID-DETERGENT FIBER}

The ADF fraction (table 2) represents essentially the ligno-cellulose fraction (8), of which the $\mathrm{Si}$ fraction is a part. It does compare more nearly to

TABLE 1.-Neutral-detergent fiber content (percent) of 10 tropical forage grasses at 6 harvest inlervals

\begin{tabular}{|c|c|c|c|c|c|c|c|}
\hline \multirow{2}{*}{ Species } & \multicolumn{6}{|c|}{ Harvest interval (days) } & \multirow{2}{*}{ Mean' } \\
\hline & 30 & 60 & 90 & 120 & 150 & 180 & \\
\hline Guinea & 74.7 & 81.3 & 82.9 & 79.1 & 79.9 & 81.5 & $79.9^{a}$ \\
\hline Buffel & 74.3 & 79.5 & 79.8 & 79.3 & 81.0 & 85.3 & $79.8^{\circ}$ \\
\hline Limpo & 70.3 & 80.3 & 81.1 & 83.2 & 76.7 & 80.8 & $78.8^{a}$ \\
\hline Signal & 62.8 & 75.3 & 76.3 & 75.5 & 81.9 & 79.3 & $75.2^{\mathrm{b}}$ \\
\hline Congo & 64.1 & 77.1 & 76.9 & 80.9 & 75.3 & 75.3 & $74.9^{\mathrm{b}}$ \\
\hline Giant Pangola & 66.0 & 74.8 & 76.6 & 74.9 & 77.2 & 75.2 & $74.1^{b}$ \\
\hline Jaragua & 68.5 & 71.7 & 72.9 & 76.4 & 75.8 & 78.3 & $73.9^{\mathrm{b}}$ \\
\hline Pangola & 73.1 & 73.8 & 73.5 & 73.6 & 69.9 & 72.9 & $72.8^{\mathrm{b}}$ \\
\hline $\begin{array}{c}\text { Venezuelan } \\
\text { Elephant }\end{array}$ & 59.1 & 73.5 & 79.0 & 77.7 & 75.2 & 72.1 & $72.8^{b}$ \\
\hline African Crab & 68.1 & 72.3 & 73.6 & 70.9 & 72.0 & 74.9 & $71.9^{\mathrm{b}}$ \\
\hline Mean & 68.1 & 76.0 & 77.2 & 77.1 & 76.5 & 77.5 & 75.4 \\
\hline
\end{tabular}

${ }^{1}$ Mean values with one or more common letter(s) are not significant at the 5percent level.

the crude fiber content (13) of the Weende method (19). However, in every forage grass, the crude fiber content is lower than the ADF content, due mainly to the loss of a large portion of the $L$ to the nitrogen-free extract fraction in the crude fiber determination (20). As a result, ADF (9) would be considered as more representative of the indigestible portion of feeds. Therefore, NDF, and particularly, ADF fractions would be classified as more precise entities than crude fiber.

Highly significant differences between species were obtained in ADF content. Guinea and Buffel grasses exhibited the highest mean values, significantly greater than all other species. Congo, Limpo, Signal and African Crab grasses presented the lowest mean values, although the differences among themselves were not significant. 
Variations in ADF content between 30-day periods were highly significant, the highest occurring between the 30 - and 60-day stages. At 30 days Guinea, Pangola and Buffel grasses were highest in ADF content, with Pangola grass increasing only 3.7 percentage units from 30 to 60 days, while all other increases ranged from 6.8 to 10.8 percentage units.

\section{HEMICELLULOSE}

The difference between the NDF and ADF fractions is an estimate of $\mathrm{H}$ (tables 3 and 4) (29), and revealed highly significant differences between species. Limpo grass presented the highest mean value, significant over all

TABLE 2.-Acid-detergent fiber content (percent) of 10 tropical forage grasses at 6 harvest intervals

\begin{tabular}{lccccccc}
\hline \multirow{2}{*}{ Species } & \multicolumn{6}{c}{ Harvest interval (days) } & \multirow{2}{*}{ Mean $^{\mathbf{2}}$} \\
\cline { 2 - 6 } & 30 & 60 & 90 & 120 & 150 & 180 & \\
\hline Guinea & 45.2 & 53.8 & 54.7 & 52.3 & 52.3 & 54.4 & $52.1^{\mathrm{a}}$ \\
Buffel & 42.0 & 50.1 & 49.7 & 53.6 & 53.0 & 53.1 & $50.2^{\text {a }}$ \\
Limpo & 37.1 & 46.0 & 45.4 & 45.4 & 42.4 & 45.4 & $43.6^{\text {do }}$ \\
Signal & 33.5 & 44.3 & 45.8 & 44.4 & 43.8 & 48.2 & $43.3^{\text {do }}$ \\
Congo & 32.8 & 43.6 & 44.6 & 48.6 & 44.6 & 47.6 & $43.6^{\text {odo }}$ \\
Giant Pangola & 38.9 & 46.6 & 46.9 & 45.2 & 47.6 & 45.7 & $45.1^{\text {bod }}$ \\
Jaragua & 37.6 & 45.6 & 45.8 & 51.1 & 50.2 & 54.6 & $47.5^{\text {b }}$ \\
Pangola & 43.7 & 47.4 & 44.3 & 45.3 & 43.2 & 45.5 & $44.9^{\text {bod }}$ \\
Venezuelan & 35.0 & 44.6 & 48.6 & 48.7 & 50.1 & 58.2 & $47.5^{\text {b }}$ \\
$\quad$ Elephant & & & & & & & \\
African Crab & 37.2 & 44.0 & 41.6 & 43.2 & 40.3 & 41.7 & $41.3^{\text {o }}$ \\
$\quad$ Mean & 38.3 & 46.6 & 46.7 & 47.8 & 46.8 & 49.4 & 45.9 \\
\hline
\end{tabular}

${ }^{1}$ Mean values with one or more common letter(s) are not significant at the 5percent level.

other species. The lowest mean values obtained in Pangola, Guinea, Jaragua and Venezuelan Elephant grasses were not significantly different among themselves.

No significant differences in $\mathrm{H}$ content were obtained between harvest dates, the $\mathbf{H}$ fraction remaining almost constant throughout the 180 days of growth.

\section{LIGNIN}

Acid-detergent $L$ (tables 3 and 4 ) is considered the least digestible of the chemical entities in forage dry matter (3). Porter (21) suggested that $L$ as measured by the acid-pepsin technique undergoes more extensive changes than the acid-detergent L, introduced by Van Soest (28). The permanganate $\mathrm{L}$ method (33) as used in this study permits a shorter procedure for $\mathrm{L}$ 
TABLE 3.-Mean hemicellulose, lignin, cellulose and silica fractions (percent) of 10 tropical forage grasses 1

\begin{tabular}{|c|c|c|c|c|c|}
\hline Species & Hemicellulose & Lignin & Cellulose & Silica & $\begin{array}{c}\text { Lignin/acid } \\
\text { detergent fiber }\end{array}$ \\
\hline Guinea & $27.8^{\text {edef }}$ & $8.4^{\mathrm{be}}$ & $41.1^{\mathrm{a}}$ & $2.5^{\circ}$ & $16.0^{\mathrm{b}}$ \\
\hline Buffel & $29.6^{\text {bed }}$ & $8.6^{\mathrm{ab}}$ & $36.7^{\text {bo }}$ & $3.6^{\mathrm{b}}$ & $17.1^{b}$ \\
\hline Limpo & $35.1^{\mathrm{a}}$ & $9.5^{a}$ & $32.5^{d o}$ & $1.4^{\mathrm{e}}$ & $21.6^{\mathrm{a}}$ \\
\hline Signal & $31.8^{b}$ & $7.1^{\text {do }}$ & $33.7^{\text {odo }}$ & $2.4^{\mathrm{ed}}$ & $16.5^{b}$ \\
\hline Congo & $31.3^{\mathrm{bc}}$ & $7.5^{\text {bed }}$ & $33.8^{\text {edo }}$ & $1.8^{\mathrm{do}}$ & $16.9^{b}$ \\
\hline Giant Pangola & $29.0^{\text {bede }}$ & $7.4^{\mathrm{od}}$ & $34.7^{\text {bede }}$ & $2.9^{\circ}$ & $16.2^{b}$ \\
\hline Jaragua & $26.4^{\text {def }}$ & $7.3^{\text {ode }}$ & $35.7^{\mathrm{bed}}$ & $4.3^{a}$ & $15.3^{b}$ \\
\hline Pangola & 27.9 edel & $7.6^{\mathrm{bed}}$ & $34.4^{\text {bede }}$ & $2.4^{\text {ed }}$ & $16.9^{b}$ \\
\hline Venezuelan Elephant & $25.2^{r}$ & $7.6^{\mathrm{bed}}$ & $37.4^{b}$ & $2.3^{\text {od }}$ & $15.7^{b}$ \\
\hline African Crab & $30.6^{\mathrm{bc}}$ & $6.3^{\mathrm{e}}$ & $31.6^{\circ}$ & $2.9^{\circ}$ & $15.2^{b}$ \\
\hline Mean & 29.5 & 7.7 & 35.2 & 2.7 & 16.7 \\
\hline
\end{tabular}

1 Mean values with one or more common letter(s) are not significant at the 5percent level.

TABLE 4.-Mean hemicellulose, lignin, cellulose and silica fractions (percent) of 6 harvest intervals

\begin{tabular}{cccccc}
\hline $\begin{array}{c}\text { Harvest interval } \\
\text { Days }\end{array}$ & Hemicellulose & Lignin & Cellulose & Silica & $\begin{array}{c}\text { Lignin/acid } \\
\text { detergent fiber }\end{array}$ \\
30 & & & & & \\
60 & 29.8 & 5.2 & 30.8 & 2.1 & 13.4 \\
90 & 29.4 & 7.2 & 36.3 & 2.5 & 15.4 \\
120 & 30.5 & 8.4 & 36.2 & 2.2 & 18.0 \\
150 & 29.3 & 8.2 & 36.1 & 2.9 & 17.3 \\
180 & 29.7 & 8.3 & 34.9 & 3.3 & 17.9 \\
Mean & 28.1 & 9.1 & 36.6 & 3.1 & 18.4 \\
\hline
\end{tabular}

per se while the residue is reserved for further analysis of $\mathrm{C}$ and $\mathrm{Si}$. Since $\mathrm{L}$ has not been defined chemically to date, Colburn and Evans (9) do not imply that the acid-detergent $L$ is a purer $L$, but rather that the acid-detergent $\mathrm{L}$ may represent a more hard-core $\mathrm{L}$.

Highly significant differences in $\mathbf{L}$ content were observed between species. Limpo grass showed the highest mean $\mathrm{L}$ content, significantly higher than all other species.

Lignin content revealed highly significant differences as the grasses advanced in maturity. Similar results were obtained by Sullivan (25), Quicke and Bentley (22) and Allison and Osbourn (1). The highest $L$ increases occurred between the 30- and 60-day stages. Pangola, Buffel and Guinea grasses were the highest in $\mathrm{L}$ content at 30 days, with Pangola grass increas- 
ing only 0.2 percentage units at 60 days. All other species varied in $\mathrm{L}$ increase from 0.6 to 4.3 percentage units.

Goering and Van Soest (16) have indicated that L is most important and is best expressed as a percentage of ADF (table 5). Statistical analyses of $\mathrm{L} / \mathrm{ADF}$ data revealed similar trends to those obtained in $\mathrm{L}$ alone.

\section{CELLULOSE}

The $\mathrm{C}$ content (tables 3 and 4) as determined by difference between ADF and $L(3,4,28)$ and by the permanganate method $(26,33)$ compares closely to $\mathrm{C}$ determined by the Crampton and Maynard method (10).

TABLE 5.-In vitro true digestibility (percent) of 10 tropical forage grasses at 6 harvest intervals 1

\begin{tabular}{|c|c|c|c|c|c|c|c|}
\hline \multirow{2}{*}{ Species } & \multicolumn{6}{|c|}{ Harvest interval (dnys) } & \multirow{2}{*}{ Mean' } \\
\hline & 30 & 60 & 90 & 120 & 150 & 180 & \\
\hline Guinea & 61.3 & 51.1 & 45.7 & 45.3 & 41.4 & 38.1 & $47.1^{b}$ \\
\hline Buffel & 69.1 & 56.3 & 50.8 & 44.1 & 36.3 & 40.3 & $49.5^{b}$ \\
\hline Limpo & 76.6 & 60.4 & 52.9 & 56.8 & 51.9 & 51.6 & $58.3^{a}$ \\
\hline Signal & 71.0 & 66.1 & 58.8 & 54.3 & 59.9 & 52.7 & $60.5^{\mathrm{a}}$ \\
\hline Congo & 76.9 & 63.9 & 60.9 & 51.8 & 55.2 & 52.9 & $60.3^{a}$ \\
\hline Giant Pangola & 78.4 & 60.2 & 57.8 & 51.6 & 50.3 & 48.6 & $57.8^{a}$ \\
\hline Jaragua & 75.8 & 64.7 & 63.0 & 55.8 & 51.9 & 51.6 & $58.8^{a}$ \\
\hline Pangola & 69.1 & 63.1 & 63.6 & 57.3 & 55.0 & 52.3 & $60.0^{a}$ \\
\hline $\begin{array}{c}\text { Venezuelan } \\
\text { Elephant }\end{array}$ & 74.5 & 63.6 & 57.0 & 50.1 & 48.6 & 42.0 & $56.0^{\mathrm{a}}$ \\
\hline African Crab & 75.6 & 55.7 & 56.6 & 51.3 & 54.4 & 57.4 & $58.5^{a}$ \\
\hline Mean & 72.8 & 60.5 & 55.7 & 51.8 & 50.5 & 48.7 & 56.7 \\
\hline
\end{tabular}

1 Mean values with one or more common letter(s) are not significant at the 5 percent level.

The C content revealed highly significant differences between species, being greater for Guinea grass than for all other species. Similar values for Guinea grass were obtained by Gomide et al. (17). Giant Pangola, Pangola, Congo, Signal, Limpo and African Crab grasses had the lowest mean $\mathbf{C}$ values, not significantly different among themselves.

Cellulose content increased in a highly significant way as grasses advanced in maturity. The largest increases were obtained between the 30 and 60-day stages in Signal (9.8\%), Congo (9.4\%) and Venezuelan Elephant (8.7\%) grasses and the lowest in Buffel (2.6\%), Pangola (2.4\%) and African Crab $(0.9 \%)$ grasses. Similar trends were observed by Gomide et al. (17) with tropical forage grasses, especially Pangola grass where $\mathbf{C}$ increases over plant age were very slight and limited to the early growth. 


\section{SILICA}

The Si compounds accumulate practically in all plant tissues, representing 3 to 5 percent of the dry matter content of many forage species $(18,23$, 32). In this study, $\mathrm{Si}$ values ranged from 0.9 to 5.3 percent of the dry matter content. In spite of the specific methodology for Si determination, it is problematic to distinguish plant-metabolized from soil-contaminated $\mathrm{Si}(32)$.

Highly significant differences were obtained in Si content (tables 4 and 5) with respect to species and age. The mean Si value for Jaragua grass was significantly greater than for all other species. Limpo grass, with the lowest mean $\mathrm{Si}$ content, maintained a uniform value during the 180 days of growth.

\section{IN VITRO DIGESTIBILITY}

Forage nutritive value includes chemical composition, intake and nutrient digestibility (5), as determined in conventional or in vivo trials. More recently, in vitro techniques $(2,5,7,16,27)$ have been developed, providing reliable estimates of in vivo results.

In vitro true digestibility (table 5) and IVAD (fig. 1) revealed highly significant differences between species. Signal, Congo, Pangola, Jaragua, African Crab, Limpo, Giant Pangola and Venezuelan Elephant grasses showed the highest mean values, not significantly different among themselves but highly significantly greater than values for Buffel and Guinea grasses.

Highly significant differences in IVTD were observed between harvest intervals as the grasses advanced in maturity, the largest mean reduction (12.3 percentage units) occurring between the 30- and 60-day stages. However, NDF, ADF, L, C and Si increased by 7.9, 8.3, 2.0, 5.5 and 0.4 percentage units, respectively.

At 30 days of age, Signal, Pangola, Buffel and Guinea grasses exhibited the lowest IVTD values. Only Buffel and Guinea grasses remained lowest in IVTD at 60 days with African Crab grass. Pangola and Signal grasses did not show a sharp reduction ( 6.0 and 4.9 percentage units, respectively), remaining among the highest at 60 days throughout 180 days. Similar results for Pangola grass at 28 and 196 days were obtained by Gomide et al. (17).

Digestibility is a variable entity, affected by $\mathrm{CP}$ and $\mathrm{ADF}$ ( $\mathrm{L}, \mathrm{C}, \mathrm{Si})$ fractions. The sharp and early reduction in IVTD from 30 to 60 days, in contrast to reductions from 60 to 180 days, occurred simultaneously with the increase in ADF, probably due to the early lignification and silicification of tropical grasses as reported by French (15). Van Soest (31) indi- 


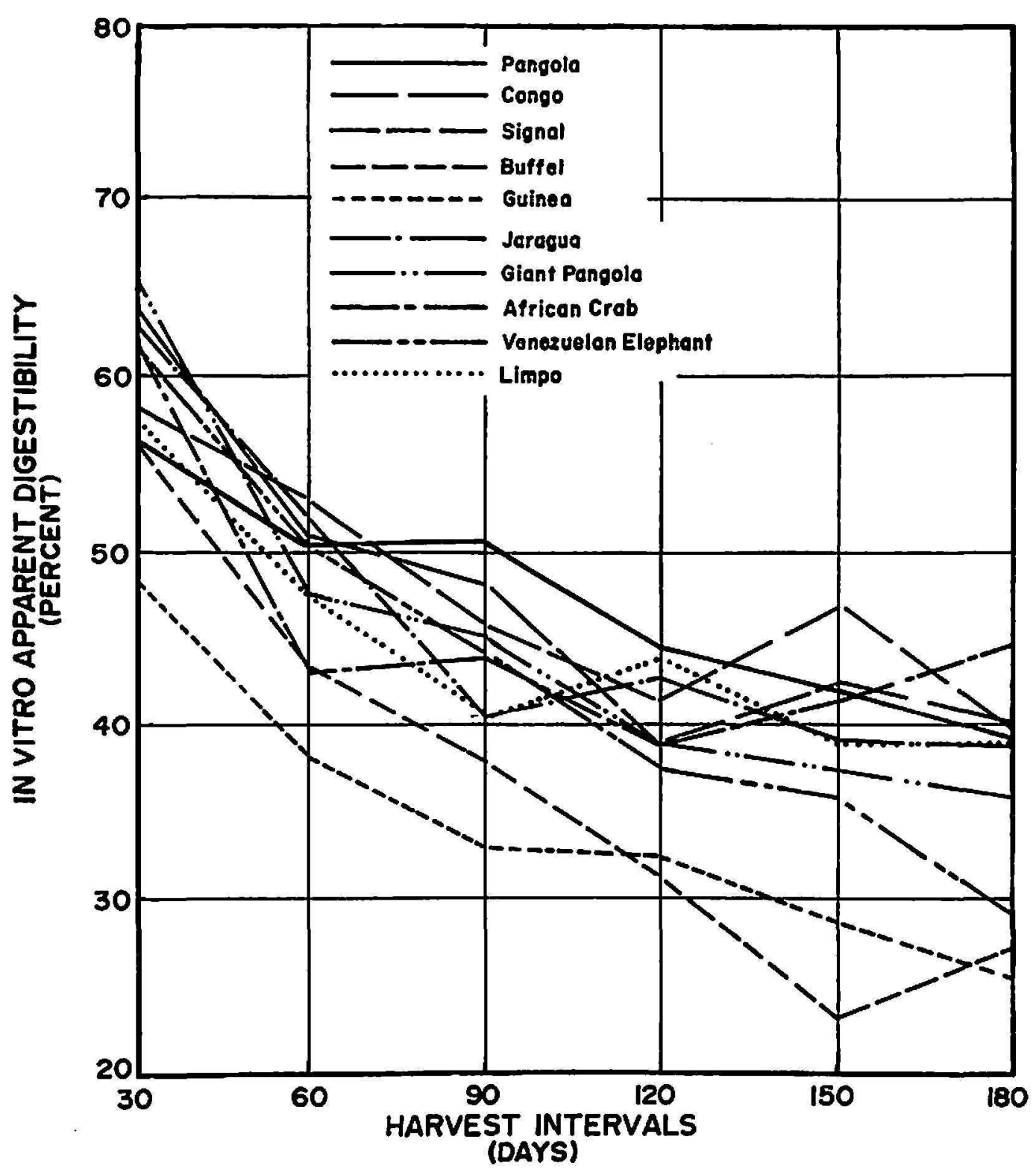

Fra. 1. Percent in vitro apparent digestibility of 10 tropical forage grasses at 6 harvest intervals.

cated that $\mathrm{L}$ is responsible for the incomplete digestibility of $\mathrm{C}$ and $\mathrm{H}$. This could occur via incrustation, but an alternative possibility is through direct linkage of $\mathrm{L}$ to the structural carbohydrates. However, French (14) and Deinum et al. (12) sustained that increased structural carbohydrates in tropical grasses are generally related to the desiccant effect of the environment causing early onset of lignification. High environmental temperature and high transpiration cause thickening of the cell walls which is necessary for support and rigidity of tropical grasses. Deinum (11) suggested that the nutritive value of tropical grasses is generally low due to the high temperatures in the Tropics that cause increased crude-fiber content but decreased protein content. 
It is evident in this study, and in Tessema's (26), that environment was not the only main effect, due to its uniformity on species growing under very similar conditions. Evidence was presented by Tessema in several forage species that revealed inherent physiological attributes to deposit chemical constituents differently in their tissues and that environmental factors were not altogether the main reasons for increased structural carbohydrates.

It may be concluded that the sharp and early change in forage quality occurred between 30 and 60 days of growth, that Pangola suffered small changes in nutritive value as compared to other species, that fibrous fractions and IVTD evaluations of all species compared favorably among themselves and that all fibrous fractions (except H) and IVTD differed significantly with plant age.

\section{SUMMARY}

Ten tropical forage grasses (Pangola, Digitaria decumbens; Congo, Brachiaria ruziziensis; Signal, Brachiaria brizantha; Buffel, Cenchrus ciliaris; Guinea, Panicum maximum; Jaragua, Hyparrhenia rufa; Giant Pangola, Digitaria valida; African Crab, Digitaria swazilandensis; Venezuelan Elephant, Pennisetum setosum; and Limpo, Hemarthria altissima) lightly fertilized with $\mathrm{NH}_{4} \mathrm{NO}_{3}$ at the rate of $350 \mathrm{~kg} / \mathrm{ha}$, were harvested by hand (machete) every 30 days up to 180 days of age, beginning August 20, 1970, at the College of Agricultural Sciences grass collection, University of Puerto Rico at Mayagüez.

They were evaluated chemically for cell-wall constituents or neutraldetergent fiber (NDF), acid-detergent fiber (ADF), permanganate lignin (L), cellulose (C) and silica (Si), as outlined by Goering and Van Soest and for in vitro true digestibility (IVTD), utilizing the Goering and Van Soest modification of the Tilley and Terry procedure. Hemicellulose $(H)$ was determined as the difference between NDF and ADF. Statistical analyses of variance were conducted.

Highly significant differences in NDF, ADF, H, L, L/ADF, C, and Si contents were observed between species. IVTD and in vitro apparent digestibility (IVAD) also revealed highly significant differences between species.

Guinea and Buffel grasses exhibited the highest mean values in NDF and ADF contents but the lowest in IVTD and IVAD, suggesting that, as total fiber and lignocellulose contents increase, digestibility decreases. Similar trends were observed in other species. Highest mean values were obtained in Guinea grass for $\mathrm{C}$, in Jaragua grass for $\mathrm{Si}$ and in Limpo grass for $\mathrm{L}$ and $\mathrm{H}$.

As the grasses advanced in maturity from 30 to 180 days, NDF, ADF, 
L, L/ADF, C and Si revealed highly significant increases while IVTD and IVAD revealed highly significant decreases with $H C$ remaining almost constant throughout. 'The largest increase in NDF, ADF, $L$ and $C$ contents and the largest decrease in IVTD and IVAD evaluations occurred between the 30- and 60-day intervals, probably due to the high environmental temperature and high transpiration causing early onset of lignification and silicification in tropical climates. Pangola grass underwent little change in nutritive value as compared to other species.

Evidence is presented that fibrous fractions and IVTD evaluations of all species compared favorably among themselves and that all fibrous fractions (except $\mathrm{H}$ ) and IVTD differed significantly with plant age.

\section{RESUMEN}

Se evaluaron muestras de las siguientes 10 yerbas forrajeras tropicales: Pangola, Digilaria decumbens; Congo, Brachiaria ruziziensis; Buffel, Cenchrus ciliaris; Guinea, Panicum maximum; Jaragua, Hyparrhenia rufa; Pangola Gigante, Digitaria valida; "African Crab", Digitaria swazilandensis; Elefante Venezolana, Penniselum selosum y Limpo, Hemarthria altissima, de $\mathbf{3 0}$ a 180 días de edad, tomadas a intervalos de corte de 30 días, comenzando el 20 de agosto de 1970.

Las yerbas se encontraban ya establecidas en parcelas con un área de $10 \mathrm{~m}^{2}$ en la colección de gramíneas del Colegio de Ciencias Agrícolas de la Universidad de Puerto Rico, localizada en Mayagüez. Se abonaron ligeramente con $\mathrm{NH}_{4} \mathrm{NO}_{3}$ a razón de $350 \mathrm{~kg} . / \mathrm{ha}$.

Se efectuaron determinaciones químico-analíticas de la fibra neutrodetergente (NDF), la fibra ácido-detergente (ADF), la lignina (L), la celulosa (C) y la sílice (Si), segán el método de Goering y Van Soest, y evaluaciones de la digestibilidad real in vitro (IVTD), según la técnica de Tilley y Terry, modificada por Goering y Van Soest. La hemicelulosa (H) se determinó como la diferencia entre la NDF y la ADF. Se hicieron análisis estadísticos de varianza.

Se encontraron diferencias altamente significativas entre las especies respecto a la NDF, la ADF, la H, la L, la L/ADF, C y Si. La IVTD y la digestibilidad aparente in vitro (IVAD) mostraron también diferencias altamente significativas entre las especies.

Las yerbas Buffel y Guinea arrojaron los valores más altos en NDF y ADF pero los más bajos en IVTD e IVAD, sugiriendo que, según aumenta el contenido de fibra total (NDF) y el de lignocelulosa (ADF), la digestibilidad disminuye. Se observaron tendencias similares en otras especies. La yerba Guinea arrojó los valores promedio más altos para la C, la yerba Jaragua para la Si y la yerba Limpo para la L y la H.

Segín fueron madurando las yerbas de los 30 hasta los 180 días de edad, los componentes fibrosos (NDF, ADF, L, L/ADF, C y Si) aumentaron mientras que la IVTD y la IVAD disminuyeron en forma altamente significativa permaneciendo la $\mathrm{H}$ casi constante.

Los mayores aumentos en NDF, ADF, L y $\mathrm{C}$ y reducciones en IVTD e IVAD, respectivamente, se observaron entre los 30 y los 60 días de edad debido probablemente a la lignificación y silicificación temprana que tienen lugar en los climas tropicales a causa de las altas temperaturas ambientales y al alto nivel de transpiración. La yerba Pangola sufrí́ cambios menores en su valor nutritivo en comparación con tres de las especies. 
Según los datos obtenidos los componentes fibrosos y la digestibilidad (IVTD) de las diversas especies eran muy parecidos entre si, pero se encontraron diferencias significativas entre los componentes fibrosos (excepto H) y la IVTD con respecto a la edad de los forrajes.

\section{LITERATURE CITED}

1. Allison, D. W., and Osbourn, D. F., The cellulose-lignin complex in forages and its relationship to forage nutritive value, J. Agr. Sci. 74: 23-36, 1970.

2. Arroyo-Aguilú, J. A., Estimation of digestibility from in vitro rumen fermentation data in some forages of Puerto Rico, J. Agr. Univ. P. R. 51 (2): 133-9, 1967.

3. - , and Evans, J. L., The use of chromium and acid-detergent lignin in complete rations as indicators of the fecal excretion rate in the ruminant animal, J. Agr. Univ. P. R. 54 (4) : 660-75, 1970.

4. - - Nutrient digestibility of lower-fiber rations in the ruminant animal, J. Dairy Sci. 55: 1266-74, 1972.

5. - - and Rivera-Brenes, L., Digestibility studies on Napier (Merker) grass (Pennisetum purpureum), Giant Pangola grass (Digitaria valida Stent), and Signal grass (Brachiaria brizantha), J. Agr. Univ. P. R. 45 (3): 148-50, 1961.

6. - Evans, J. L., and Taylor, M. W., The artificial rumen technique for estimating the nutritive value of forages, J. Agr. Univ. P. R. 47 (3): 169-79, 1963.

7. Baumgardt, B. R., Taylor, M. W., and Cason, J. L. Evaluation of forages in the laboratory, II, Simplified artificial rumen procedure for obtaining repeatable estimates of forage nutritive value, J. Dairy Sci. 45: 62-8, 1962.

8. Colburn, M. W., and Evans, J. L., Chemical composition of the acid-detergent fraction of orchardgrass, alfalfa and mixed forages, Abstr., J. Dairy Sci. 48: 1,557-8, 1965.

9.,-- Chemical composition of the cell-wall constituent and acid-detergent fiber fractions of forages, J. Dairy Sci. 50: 1,130-5, 1967.

10. Crampton, E. W., and Maynard, L. A., The telation of cellulose and lignin content to the nutritive value of animal feeds, J. Nutr. 15: 383-95, 1938.

11. Deinum, B., Climate, nitrogen and grass, Research into the influence of light intensity, temperature, water supply and nitrogen on the production and chemical composition of grass, Meded. Landb. Hogesch. Wag. 66-11, 1-91, 1966.

12. - - van Es, A. J. H., and Van Soest, P. J., Climate, nitrogen and grass, II, The influence of light intensity and nitrogen on in vitro digestibility of grass and the prediction of these effects from some chemical procedures, Neth. $J$. Agr. Sci. 16: 217-23, 1968.

13. Fonnesbeck, P. V., Digestion of soluble and fibrous carbohydrate of forage by horses, J. Anim. Sci. 27 : 1,336-44, 1968.

14. French, M. H., Nutritional value of tropical grasses and fodder, Herbage Abstr. $27: 1-9,1957$.

15. - The nutritive value of East-African hay, Emp. J. Agr. Res, 24: 53-60, 1956.

16. Goering, H. K., and Van Soest, P. J., Forage fiber analyses (apparatus, reagents, procedures, and some applications), USDA Agr. Handbook 379, 1970.

17. Gomide, J. A., Noller, C. H., Mott, G. O., Conrad, J. H., and Hill, D. L., Effect of plant age and nitrogen fertilization on the chemical composition and in vitro cellulose digestibility of tropical grasses, Agron. J. 61: 116-20, 1969. 18. Jones, L. H. P., and Handreck, $\mathbf{K}$, A., Silica in soils, plants and animals, Ad-
vances in Agron. 19: 107-12, 1967. 
19. Maynard, L. A., and Loosli, J. K., Animal Nutrition, 6th ed., McGraw-Hill Book Co., Inc., New York, N. Y., 1965.

20. Norman, A. G., The composition of crude fiber, J. Agr. Sci. 25: 529-40, 1935.

21. Porter, P., Lignin as an inert marker in studies of ruminant digestion, Abstr., Proc. Nutr. Soc. 24: VI-VII, 1965.

22. Quicke, V. G., and Bentley, O. G., Lignin and methoxyl groups as related to the decreased digestibility of mature forages, J. Anim. Sci. 18: 365-73, 1958.

23. Smith, G. S., Nelson, A. B., and Boggino, E. J. A., Digestibility of forages in vitro as affected by content of silica, J. Anim. Sci. 33: 466-71, 1971.

24. Snedecor, G. W., and Cochran, W. G., Statistical Methods, 6th ed., The Iowa State Univ. Press, Ames, Iowa, 1967.

25. Sullivan, J: T., Cellulose and lignin in forage grasses and their digestion coefficients, J. Anim. Sci. 14: 710-7, 1955.

26. Tessema, S., Nutritional value of some tropical grass species compared to some temperate grass species, $\mathrm{Ph}$. D. Thesis, Cornell Univ., 1972.

27. Tilley, J. M. A., and Terry, R. A., A two-stage technique for the in vitro digestion of forage crops, J. Brit. Grassland Soc. 18: 104-11, 1963.

28. Van Soest, P. J., Use of detergents in the analysis of fibrous feeds, II, A rapid method for determination of fiber and lignin, J. Assoc. Off. Agr. Chem. 46: 829-35, 1963.

29. - Nonnutritive residues: A system of analysis for the replacement of crude fiber, J. Assoc. Off. Anal. Chem. 49: 546-51, 1966.

30. - Development of a comprehensive system of feed analyses and its application to forages, J. Anim. Sci. 26: 119-28, 1967.

31. - Structural and chemical characteristics which limit the nutritive value of forages, Forage: Economics/Quality, A.S.A. Special Publ. 13, 1968.

32. —, and Jones, L. H. P., Effect of silica in forages upon digestibility, J. Dairy Sci. 51 : 1644-8, 1968.

33. - , and Wine, R. H., Determination of lignin and cellulose in acid-detergent lignin with permanganate, J. Assoc. Off. Anal. Chem. 51: 780-5, 1968.

34. - - - - and Moore, L. A., Estimation of the true digestibility of forages by the in vitro digestion of cell walls, Proc. X Inter. Grassland Cong. 438-41, 1966. 